brazilianpoliticalsciencereview

ART I CLE

\title{
The Institutional Presidency from a Comparative Perspective: Argentina and Brazil since the 1980s*
}

\author{
Magna Inácio \\ Universidade Federal de Minas Gerais, Brazil \\ Mariana Llanos \\ GIGA Institute of Latin American Studies, Germany
}

This paper focuses on the evolution of the institutional presidency - meaning the cluster of agencies that directly support the chief of the executive - in Argentina and Brazil since their redemocratization in the 1980s. It investigates what explains the changes that have come about regarding the size of the institutional presidency and the types of agency that form it. Following the specialized literature, we argue that the growth of the institutional presidency is connected to developments occurring in the larger political system - that is, to the political challenges that the various presidents of the two countries have faced. Presidents adjust the format and mandate of the different agencies under their authority so as to better manage their relations with the political environment. In particular, we argue that the type of government (coalition or single-party) has had consequences for the structure of the presidency or, in other words, that different cabinet structures pose different challenges to presidents. This factor has not played a significant role in presidency-related studies until now, which have hitherto mostly been based on the case of the United States. Our empirical references, the presidencies of Argentina and Brazil, typical cases of coalitional as well as single-party presidentialism respectively allow us to show the impact of the type of government on the number and type of presidential agencies.

Keywords: Argentina; Brazil; institutional presidency; presidential office; coalition presidentialism.

(*) http://dx.doi.org/10.1590/1981-38212014000200002

The replication dataset can be found in http://bpsr.org.br/files/arquivos/Banco_Dados_ Inacio_Llanos.html 


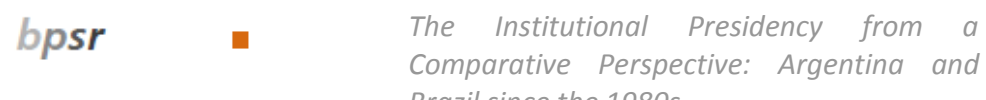
Brazil since the 1980s

2 residents are undoubtedly the most powerful political actors in Latin American democracies. They enjoy significant policy-making powers in multiple policy realms as a means to influence the legislative agenda, control the allocation of resources, appoint and dismiss thousands of different government officials, and respond directly to the demands of their electorate. But even the most influential presidents need the political support and technical assistance of trusted advisors, technical staff, and government agencies. Students of the United States' presidency have shown that presidents have incentives for creating and strengthening technical, administrative, and advisory presidential support bodies both to confront critical junctures - the modern US presidency emerged in the wake of the Great Depression - and to help face the challenges that are posed in a system characterized by "separate institutions sharing powers". At the same time, scholars have also documented the increasing centralization of authority around the person of the chief executive and the steady movement toward the institutional reinforcement of the political core executive as developments that have taken place in most advanced industrial countries in the last forty to fifty years (PETERS et al., 2000).

In Latin America, the distinction between executive leadership and the institutional nature of the modern presidency has not been really addressed yet, despite there having been a significant expansion of studies on presidentialism. For a long time, a history of democratic and institutional instability drove researchers' attention to other crucial topics which were, to a great extent, connected to the survival of presidential regimes (LINZ, 1990). However, after decades of democratic rule in the region, presidential scholars have become more concerned with themes that also interest their US counterparts, such as those dealing with managerial issues of governance ${ }^{1}$. In this paper, we focus on the presidencies of Argentina and Brazil since their redemocratization in the 1980s in

\footnotetext{
${ }^{1}$ In effect, in the last couple of years there has been progress in the field of presidential studies in Latin America: some publications have begun to tackle conceptual issues (BONVECCHI and SCARTASCINI, 2014; LANZARO, 2012), in conjunction with others dealing with case studies (MÉNDEZ, 2007, on the case of Mexico; LANZARO, 2013, on Uruguay; COUTINHO, 2008, on Argentina). Similarly, the recent creation of the Group for Executive Studies (GEE), within the framework of the Latin American Association of Political Science (ALACIP), indicates an awakening interest in the field. Still, we have not identified any comparative effort similar to the one we present in these pages.
} 
order to shed light on this underresearched topic. Our study of the presidency concentrates on the cluster of agencies that directly support the chief executive; this is called the "core executive" (PETERS et al., 2000) or the "institutional presidency" (MOE, 1993; 1994) in the presidential studies literature ${ }^{2}$. These agencies are part of the bureaucracy of the executive branch, but they are not located within the executive cabinet; their defining characteristic is that they operate under the direct authority of the president and are responsible for supporting the presidential leadership (DICKINSON, 2005). Following the specialized literature, we argue that the growth of the institutional presidency is connected to developments occurring in the larger political system - that is, to the governmental and political challenges that presidents face (MEZEY, 2013; MOE, 1985; PONDER, 2012). Presidents adjust the format and mandate of the different agencies under their authority so as to better manage their relations with the wider political environment.

We observe reverse developments having taken place after the democratic transitions in both Argentina and Brazil, where the institutional presidency has at times been expanded and at other times reduced - and we thus inquire into the causes of such evolutions. These movements have not only affected the size of the institutional presidency but also the types of agencies that form it. Regarding size, we borrow from Terry Moe (1985; 1993; 1994), and call any increase in the number of presidential agencies "centralization". For Moe, a centralizing movement indicates a shifting of the functions of the wider executive branch to the core executive; while, conversely, presidents "decentralize" when they take agencies away from their direct authority and place them under the authority of a cabinet minister. Regarding the types of agencies, making changes to those under the presidential umbrella can affect their substantive tasks in terms of providing core administrative, policy, or advisory support (INÁCIO, 2012). In the following pages, we: analyze the creation, transfer, and/or dissolution of presidential agencies; compare how the blueprint of the institutional presidency looks in

\footnotetext{
2 In this paper we make an indistinct use of the terms "institutional presidency" and "presidential office" to refer to the group of agencies located directly under the president's authority. Later on we operationalize the term "Institutional Presidency" (IP), which we use to refer specifically to all agencies under the president's authority excluding the decentralized ones. More details on this are given in Section 3.
} 


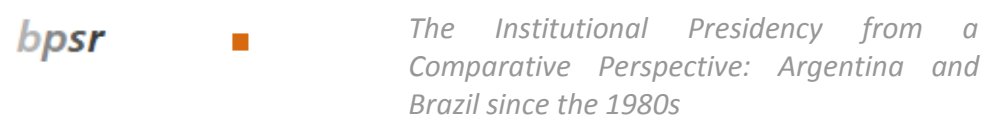

Argentina and Brazil over time; and, search for the causes of the differences between the two cases.

We argue that the type of executive cabinet - a factor that until now has not played a significant role in presidential studies, which are mostly based on the US case - poses various challenges to presidents and, thus, impacts differently on the structure of the presidency. Our empirical references, the presidencies of Argentina and Brazil and typical cases of single-party and coalitional presidentialism, respectively, allow us to test the impact of the aforementioned factor. In effect, we expect to find greater centralization under coalition presidentialism because presidents must share cabinet positions, negotiate, and manage relations with coalition partners. In single-party governments, meanwhile, presidents can more freely assert themselves over the whole executive structure; in other words, centralization should be less necessary. Similarly, we expect the type of government to affect the types of agencies that form the institutional presidency, with coalition presidents building a more complex and varied presidential institution.

The literature on presidentialism, particularly that which focuses on coalition experiences in Latin America, sheds light on the "executive toolbox" that is available to the different heads of state for building legislative majorities (RAILE, PEREIRA and POWER, 2011). Our analysis highlights a specific tool herein that previous studies on this region have not yet explored: the strategic redesign of the bureaucratic structures of the presidential office, undertaken by the president. It suggests that presidents can use the making of structural changes in their office as a tool with which to manage their relations with the wider political environment in general, and with the cabinet in particular. These changes are resources that the president can use to complement or substitute other tools, such as agenda-setting power or pork and ministerial nominations - which are those aspects usually highlighted in the aforementioned literature (ALTMAN, 2000; AMORIM NETO, 2000; FIGUEIREDO and LIMONGI, 1999; MARTINEZ-GALLARDO, 2012).

The paper is organized as follows: The next section presents the theoretical background to our study of the institutional presidency, with emphasis on the existing theories about the growth of the US presidency and with references to the main features of the Argentine and Brazilian political systems. Next, Section 
3 deals with the research question, data, methodology, and the results obtained from our empirical study. Section 4 then concludes by outlining our pending tasks as researchers, and by suggesting the implications of our work for the agenda of presidential studies on Latin America henceforth.

\section{State of the Art}

There are three prominent explanations given for the emergence and growth of the institutional presidency: increased government responsibilities, the reassertion of the presidential leadership vis-à-vis the political environment (Congress and the general public), and the more astute management of cabinet politics.

The expansion of the governance capacity of the executive to deal with major social and economic challenges is one of the classical explanations given for the growth of the US institutional presidency. Beginning in the late nineteenth century, but becoming particularly marked in the early twentieth century, the role of government both in the US and elsewhere began a steady expansion, with increased responsibilities coming therewith. This had a profound effect on the size and political role of the executive branch, giving rise to the bureaucratic state. The enlargement of the executive branch gave greater prominence and power to the president, but also brought about many problems because presidents were now expected to manage both all of their old responsibilities and the new challenges as well (MEZEY, 2013, pp. 99-103). According to this line of analysis, presidents developed incentives for creating and enlarging the technical, administrative, and advisory presidential support bodies so as to confront critical challenges (national security threats, recessions, popular unrests) and to handle increasing responsibilities, such as was the case for President Franklin D. Roosevelt during the Great Depression (PELIKAN, 2005, p. XV). Exponents of this thesis are, for instance, Ragsdale and Theis (1997), whose model demonstrates that the growth of the presidential institution matches more the increase in government responsibilities and presidential workload over the course of decades than it does individual presidential styles or the political conditions under which they work.

Ragsdale and Theis (1997) maintain that the rudiments of the US presidential institution began in 1924 with the creation of the Bureau of the 
Budget, although most scholars consider that 1939 marks the completion of the institution's formal creation with the founding of the Executive Office of the President (EOP), the transfer of the Bureau of the Budget to the EOP, and the creation of the White House Office within the EOP. Interestingly, the establishment of the EOP was contemporaneous with the beginnings of presidential organizations in Argentina and Brazil. In Argentina, these agencies grew considerably under the de facto presidency of General Ramirez (beginning in 1943), who created not only the General Secretariat of the Presidency (with the status of a ministry) but also the Secretariat of Labor and Social Security (BONIFACIO and SALAS, 1985). The latter was renowned for serving as the launching pad for Colonel Juan Domingo Perón's presidential career. In the case of Brazil, the strengthening of the federal government took place in the 1930s and the presidential organization underwent a remarkable change during these years. In addition to the General Consultation Unit, Getulio Vargas' government created the Civil and Military Cabinets and the Administrative Department of Public Service (DASP), that turned the presidency into a more complex organization. Although the changes had been carried out within the restrictions of a dictatorship, this internal means of organization was retained by the presidents of the democratic period up until 1964.

A second thesis posits that the predominant explanation for the expansion of the institutional presidency is the president's need to influence policymaking. The post-Franklin D. Roosevelt expansion is thus portrayed as an attempt to mitigate the role of Congress in the appointment, dismissal, and oversight of government officials and to reassert strong administrative leadership (HOWELL, 2003). Terry Moe's take on the "politicized presidency" (1985) shows how presidents respond to limited formal authority and increased expectations of presidential power by structuring and staffing the bureaucracy in a way that makes the different agencies responsive to presidential dictates. Similarly, Rudalevige (2002) and Rudalevige and Lewis (2005) have argued that centralization under presidential authority is a presidential strategy adopted to overcome hostile congressmen and bureaucracies in order to implement new policy agendas. There have been many other studies focusing on the impact of the president's political constraints on the institutional presidency. Dickinson (2000) 
connected the growth of the White House staff to presidential bargaining with Congress and to what occurred in the electoral arena. Krause (2002) found that changes in EOP expenditures are primarily explained by the institutional rivalry between the president and Congress. Dickinson and Lebo (2007) determined that it is primarily the White House's staff growth that is affected by presidents' evolving political relations, while the advent of "big government" more generally is a a better explanation for the growth of the EOP as a whole.

In Latin America, presidents count on a wide array of powers to improve their ability to govern. These strong constitutional prerogatives suggest the prevalence, there, of the president's own preferences and leadership style in the construction of the presidential institution ${ }^{3}$. They also suggest that the Latin American presidency has a great ability to adapt to changes in the political environment (HUNTINGTON, 1968). First, Argentine and Brazilian presidents can resort to the use of important constitutional resources to negotiate the policy agenda with Congress, such as issuing decrees with the force of law as well as total or partial vetoes (SHUGART and CAREY, 1992). Second, while US presidents share authority with Congress over the appointment of cabinet members and other important government staff, most Latin American presidents only appoint such individuals by the signing of an ordinary decree: the organization of the executive cabinet and the appointment strategy is the presidential calculus (AMORIM NETO, 2006). Equally, they do not need congressional authorization to remove government officials from their job. Third, the US Congress participates in the design and oversight of the most important executive agencies and all important social programs; also, government agencies require some sort of congressional approval. Although Congress must still approve major structural changes in the executive branch, the Latin American situation is looser. These features make us

\footnotetext{
${ }^{3}$ At this point we acknowledge the extensive and rich literature, mostly on the US case, dealing with the incumbents rather than with the presidential institution. Classical works refer to different aspects of presidential leadership (NEUSTADT, 1960; SKOWRONEK, 1997), often drawing from behavioural and cognitive psychology (GREENSTEIN, 2009; GEORGE AND GEORGE, 1998). The contributions of this area of presidential studies are worth stressing, and are also underresearched in Latin Latin America (see MÉNDEZ, 2013). Our interest, however, is more centred on institutions than leaders. We understand that, to overcome idiosyncratic analyses based on individual cases (and even individual leaders) and to progress in the field of comparative presidential studies, we need to concentrate first on the institutional developments.
} 
expect ebbs and flows in the agencies comprising the presidency in these countries, rather than a process of institutionalization. However, the Argentine and Brazilian presidents also preside over systems characterized by federalism, a symmetrical bicameral system, a judiciary with review powers, and multiparty systems that impede the reaching of sufficient support for the president in the assembly - these are far-reaching systems of constraints that should induce the construction of some permanent bases of support for the president within the executive architecture.

Finally, the literature has thus far been silent on the impact of the type of executive cabinet, a point on which Argentina and Brazil - as well as many other Latin American countries besides - differ. But there are good reasons to expect that single-party and multiparty cabinets demand different management skills from presidents, and that the political composition of cabinets affects the structure of the institutional presidency. In Brazil, an electoral system of proportional represention with an open list and no effective national threshold for representation in the federal Congress generates a highly fragmented electoral and legislative party system (AMES, 2001). As a consequence, all Brazilian democratic presidents have been minority presidents - no party since 1990 has controlled more than 20 percent of the seats in either the Senate or the Chamber of Deputies. In Argentina, Peronist presidents (1989-1999; 2001-the present) ruling during most of the democratic era have managed majorities or near-majorities in both chambers, although certainly not for the entire duration of their terms. To manage their minority status, Brazilian presidents have been running coalition governments since the return to democratic rule, except during President Collor's tenure (1990-1992) ${ }^{4}$. In Argentina, there have been technocrats, independents, and other party members participating as individuals in the cabinet, but a government coalition has only ruled for two years (1999-2001) since 1983. After the 2001 crisis that caused President De la Rúa's resignation, two successive presidents were elected by Congress to finish his term (Adolfo Rodríguez Saá and

\footnotetext{
${ }^{4}$ Although Collor de Melo appointed politicians of different political parties in his cabinet as many Latin American presidents also do - his government is not considered a coalitional government. We, consistent with most of the literature, consider a government as coalitional when party leaders are appointed as representative of their parties and with the purpose to strengthen presidential support in Congress through their legislative contingents.
} 
Eduardo Duhalde), the latter with the support of a broad multiparty parliamentary - and then also cabinet - coalition.

Thus, an important difference between Argentina and Brazil seems to be the distance between the preferences of the president and those of his cabinet. Brazilian presidents appoint ministers from different parties to comply with coalition agreements and cannot easily dismiss them without putting the coalition itself in danger. When cabinet positions are distributed to fulfill coalition agrements, the president's ministers are not his personal trustees - and he or she has incentives to grow the bureaucratic structure under his or her direct authority so as to coordinate and solve distributional conflicts among cabinet members. In contrast, Argentine presidents do not normally adhere to coalition pacts and can more freely exercise their appointment and dismissal prerogatives. Certainly, the distance between preferences may still be large, concerning the presidential relations with other institutions such as Congress and the bureaucracies, but it should not be so pronounced as to affect the daily functioning of the cabinet.

In short, the centralization of agencies and personnel under direct presidential authority is a typical mechanism with which presidents have responded to developments occuring in the wider political system (PONDER, 2012). The growth of the institutional presidency has been connected to the need to confront critical contextual challenges, increasing government responsibilities, and political and institutional uncertainties. We assume that it is also connected to the tasks of cabinet management. In the following empirical sections we attempt to estimate the relative weights of these different factors for the specific cases of Argentina and Brazil.

\section{Data and Methodology}

Contradictory trends of centralization and decentralization occurring over time have been intrinsic to the development of the modern presidency in Latin America and beyond. Some agencies survive several different administrations and become stable components of the presidency; others, instead, are soon abolished or- more often - are moved to other areas of the executive branch. Therefore, every year agencies of different types and durations coexist under the president's authority (RAGSDALE AND THEIS, 1997). Graph 01 depicts the total number of 
agencies under presidential authority in Argentina and Brazil per year from 1984 until 20105. There are two lines for each country in this graph: the dotted line indicates the decentralized (autárquicas) units (AU), which are those structurally subordinated to the president but with budgetary and administrative autonomy; the continuous line shows the units belonging to what, in the legal structures of these countries, is called the "central administration" - which we, as noted, refer to as the "Institutional Presidency". In effect, for the purpose of this study, we operationalize the institutional presidency (henceforth, IP) as the group of agencies directly located under the presidential authority and excluding the decentralized ones.

The lines of the IP for both countries show a smaller and more compact structure at the beginning of the democratic period. Afterward, there is considerable annual variation - but as part of a more general country-specific tendency. The Argentine line moves up and down, while in Brazil there is a clear upward tendency. This happens also with the lines corresponding to the AU, which are comparatively fewer for the Brazilian presidency but also on the increase at the end of the period studied. It is clear that, during the first half of the democratic period, Argentine presidents tended to "centralize" agencies under their direct authority while in the last years they reversed this tendency, undertaking instead a process of decentralization.

The oscillations that Graph 01 illustrates have given way to different makeups for the two IPs throughout the years. In the following, we are first interested in exploring what factors have affected the size of the IP in the two countries and, second, in what types of agencies constitute the IP. This is because, as our theoretical framework indicates, changes in the political environment should not only alter the size of the IP but its internal features as well. In order to address these two questions, we conducted a two-step analysis: First, we

\footnotetext{
5 To count these for Argentina, we relied on information concerning the national budget. According to this approach, a unit was considered to be such when it had a budget allocation. However, we also needed to resort to secondary sources because detailed budgets have only been available since 1993. Therefore, the graph includes information obtained from other authors as well (COUTINHO, 2008; BONIFACIO AND SALAS, 1985), particularly for the 1980s. For Brazil, we considered the legal provisions that distinguish the units of the presidency as direct administration, which are different from subordinated agencies, such as foundations and public companies.
} 
estimated the effects of a set of political and contextual variables on the size of the IP by means of a regression model that is presented hereafter. Second, we undertook an exploratory qualitative analysis of the types of units composing the IP.

Graph 01. Number of institutional presidency units and decentralized units of the presidency in Argentina and Brazil, 1984-2010

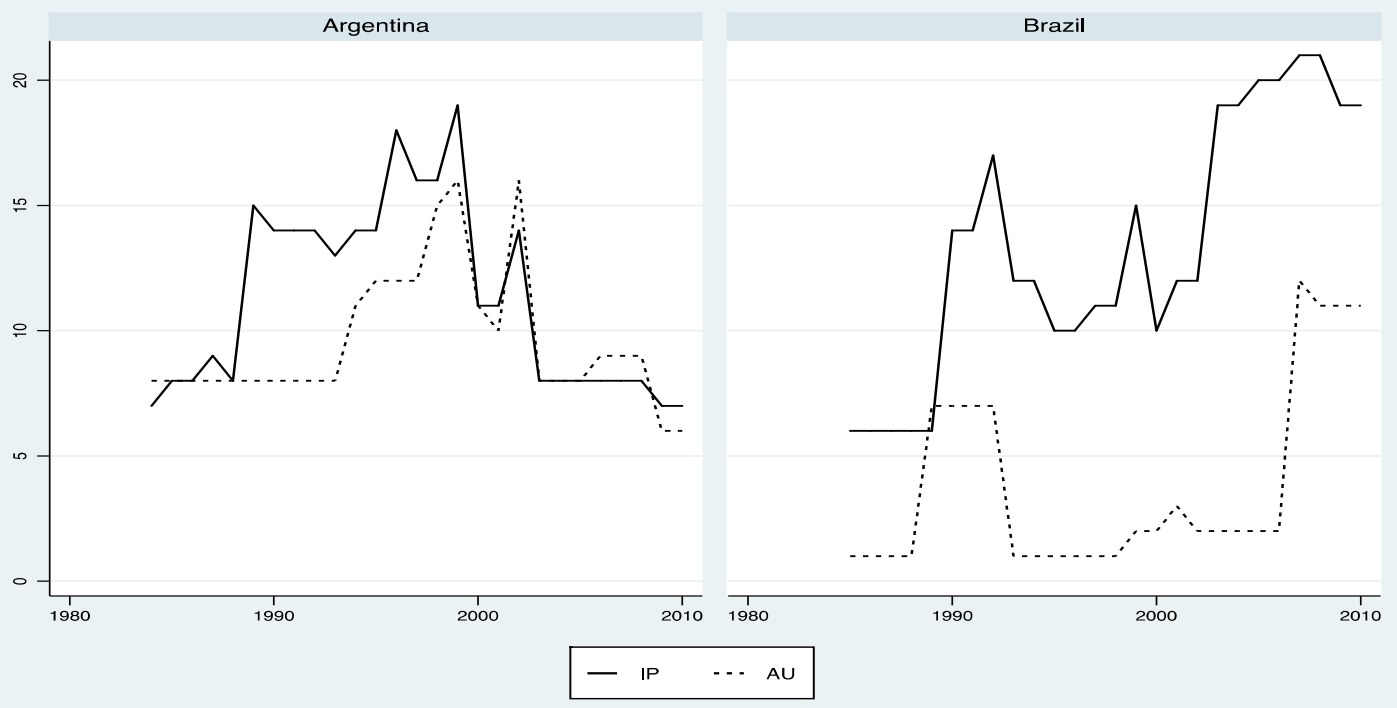

Graphs by Country

Source: INACIO_LLANOS_DATABASE.

\section{The Size of the Presidencies}

In this section we are interested in the number of organizational units belonging to the institutional presidency of a given country for each year, which is our dependent variable (prunits in Table 01). The database contains 53 records of the number of IP units per annum: there are 27 entries for Argentina and 26 for Brazil, respectively. This database includes six Argentine presidents (Alfonsin, Menen, De la Rúa, Duhalde, and Kirchner) and four Brazilian ones (Sarney, Collor, Cardoso, and Lula). Table 01 also presents the independent variables that we expect to have had an impact on the size of the institutional presidency. These are related to the three general dimensions that were referred to in Section 02: president-cabinet relations (or type of executive cabinet); president-congress relations (or the extent of political support); and, the president vis-à-vis the public's support. Our assumption about the behavior of these variables is that the number of IP units will increase - or the institutional presidency will grow - in 


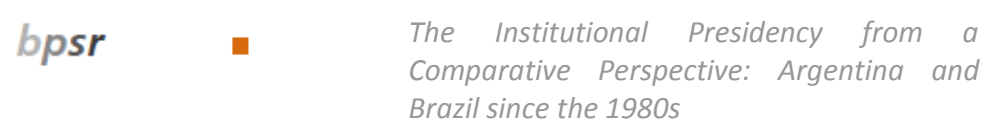

response to the constraints of a political environment that can be a potential challenge to the presidential leadership. To account for president-cabinet relations, we gathered information on the composition of the government. As explained previously, we expect coalition governments - and, particularly, a high number of parties in the cabinet - to have a positive impact on the size of the institutional presidency ${ }^{6}$. In other words, political fragmentation within the cabinet, and its consequent spurring of demands for coordination efforts, should encourage the creation of support units under the authority of the chief executive. In order to better understand the impact of the internal dynamics of the government upon the size of the presidency, we included the variable cabpart (see Table 01), which is based on a count of the number of coalition parties that were part of the ministerial portfolio.

Table 01. Descriptive statistics - dependent and explanatory variables

\begin{tabular}{lccccc}
\hline Variables & Obs & Mean & Std Dev. & Min & Max \\
\hline Prunits (dep. variable) & 53 & 12.3208 & 4.5942 & 6 & 21 \\
Cabpart & 53 & 2.8868 & 2.5545 & 1 & 9 \\
Popularity & 53 & 41.4068 & 20.4088 & 7 & 82 \\
Reform & 50 & .5472 & .1007 & .3 & .66 \\
Dummies & & & & & \\
Resignation & 53 & .0943 & .2951 & 0 & 1 \\
Seats_dum & 53 & .5472 & .5025 & 0 & 1 \\
\hline
\end{tabular}

Source: INACIO_LLANOS_DATABASE.

Interbranch conflicts are one incentive for the expansion of the institutional presidency. In the US presidency-related literature, the logic underlying this reasoning is the shared power that both branches have to authorize structural changes and appointments in the executive branch - which in the case of a divided government scenario would give more power to the congressional opposition. To be able to implement his or her policy agenda in a restrictive political environment, the president may seek to centralize agencies under his or her direct control - thus enlarging the size of the institutional presidency. Congressional bodies in Latin America have less power over the

\footnotetext{
${ }^{6}$ Although, as we have stated before, presidents can appoint members of different parties in the cabinet, the simple presence of partisan ministers does not involve the forming of a coalition. We only count parties in the cabinet when their presence involves the formation of a government coalition.
} 
executive branch than the US congress has, but their approval is still required for major structural changes to be made. We included a variable that addresses the political support for the government in the legislative arena. We gathered information on the proportion of legislative seats controlled by all governing parties in the lower house and built a dummy variable indicating whether the president is supported by a majority (more than 50 percent of seats) or not (seats_dum, the last line in Table 01). The majority status was observed in 33.3 percent and 76.9 percent of cases in Brazil and Argentina, respectively. We expect a majority status to have a negative impact on the size of the institutional presidency ${ }^{7}$.

In addition to these two main explanatory variables, we include a set of political and economic control variables that aim to measure the power of presidents in more general terms. First, we considered the president's approval rating (popularity), measured as a percentage of positive survey responses ("great" or "good") in polls about the performance of the president. This variable presents the yearly average for such positive approval ratings, and should have a negative impact on the presidency's growth: a president doing well would not need to expand her support structures. Second, as presidential resignation is not an uncommon event in our data - there were five occurrences thereof across 11 presidential terms - we thus include a dummy variable (resignation) indicating whether the president assumed her position in the wake of a previous incumbent's resignation. Caretakers will not have incentives to introduce major changes because they will try to avoid making disruptive decisions in a context of inherited conflict. Finally, alongside the political control variables, we intend to capture the impact of economic reforms on the expansion of the institutional presidency by means of the Structural Reform Index (SRI), as calculated by Lora (2012). The SRI is an average of partial indices in five policy areas: privatization, financial and trade liberalization, labor regulation, and tax reforms. The closer the measure is to

\footnotetext{
${ }^{7}$ Certainly, this variable is not able to grasp the different compositions of those majorities - particularly the heterogeneous political nature of the large Brazilian ones. Therefore, we created a second variable that only includes the seats of the presidential party. The presidential party represents, on average, 46 percent of the deputies in Argentina, while the presidents in Brazil have been supported by an average of 19.7 percent. However, this variable is strongly correlated to seats_dum and cabpart, and we did not include it in the regression model.
} 
one, the greater the degree of general market reform occurring in that country at that time. We expect the reform variable based on the SRI to have a positive effect on the size of the institutional presidency, because of the coordination efforts that are required to lead these types of reform.

We fitted population-averaged panel data models by using generalized estimating equations (GEE) with a Poisson error and link log. Below, we report the estimated relative risks (IRR), standard errors, and levels of statistical significance (Table 02). In the final count, we worked with 50 observations because of restricted data availability regarding the reform variable (which did not cover the years 1984, 1985, and 2010).

Table 02. Estimated regression coefficients and standard errors (GEE - Poisson)

\begin{tabular}{lc}
\hline Explanatory variables & Relative risks (IRR) \\
\hline Majority status (dummy) & $.8215884^{*}$ \\
Cabpart & $(0.084)$ \\
& $1.075624^{* * *}$ \\
Popularity & $(0.021)$ \\
& .9981615 \\
Reform & $(0.002)$ \\
& $3.213858^{* *}$ \\
Resignation & 1.644 \\
N & .9194901 \\
Deviance & $0.163)$ \\
\hline
\end{tabular}

Source: INACIO_LLANOS_DATABASE.

Note: The dependent variable is the number of organizational units within the CA in a given year. Standard errors are given in parentheses. Coefficient estimates from the GEE regression model with poisson error and link log. Significance levels : $*: 10 \% * *: 5 \% * *$ $*: 1 \%$.

Our variable cabpart - the number of coalition parties in the cabinet (cabpart) - behaves as expected: as the number of parties in the cabinet increases, so does the size of the institutional presidency. In other words, the size of the IP increases by 7 percent for each party taking a seat in the cabinet $(p<0.01)$. These results support our hypothesis about the impact of the type of cabinet on the size of the presidency. The second dimension considered was president-congress relations, which was measured by the majority status of the government in the 
lower chamber. Holding a legislative majority decreases the size of the presidency by 17 percent, in line with our hypothesis - this effect is statistically significant $(\mathrm{p}<0.10)$.

Regarding the contextual variables, presidential popularity represented a negative effect - as we hypothesized. It suggests that a popular president has fewer incentives to invest time and resources in enlarging the presidency, and that he or she probably does not need a large structure of support backing him or her. Also, after a presidential resignation, the successor centralizes less power and keeps a smaller IP than presidents assuming the position after regular elections. However, the effect of both variables is not statistically significant. The relative risks posed by economic reforms show us that these types of challenges exert pressure on the presidency. An increase of one point in the SRI increases the size of the institutional presidency by 221 percent $(\mathrm{p}<5)$. Figure 1 summarizes the expectations and the actual direction of the effects of the explanatory variables on the dependent variable, the annual number of IP units.

Figure 01. Expected and actual sign of estimated coefficients

\begin{tabular}{lccl} 
Explanatory & Expected sign & Actual sign & Sig level \\
Variables & & & \\
\hline Cabpart & + & + & $* *$ \\
Majority status & - & - & $*$ \\
Resignation & - & - & \\
Popularity & - & - & \\
SRI & + & + & $* *$ \\
\hline
\end{tabular}

Source: INACIO_LLANOS_DATABASE.

Note: Significance levels : $*: 10 \% * *: 5 \% * * *: 1 \%$.

In sum, presidents respond strategically to these different challenges by increasing the size of their offices. Particularly, the presidency grows with the increase in the number of parties inside the cabinet - a feature associated with coalition presidentialism. This shows that presidents need to enlarge their organizational support when their governmental team is internally fragmented. However, it also suggests that more parties in the cabinet implies less resources for presidential patronage and that the presidential offices may be fulfilling this patronage function instead. This is something that needs to be explored more carefully. In addition, it is interesting to note that presidents have invested in enlarging their organizations in order to implement economic structural reform. 


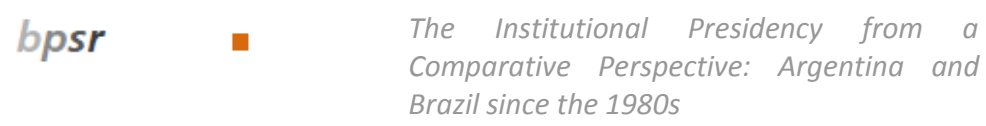

This type of reform deepens the tensions within the government because it impacts on the supporters of the cabinet's parties. Our findings suggest that coalition governments pursuing structural reforms have more incentives to centralize functions and resources within the presidency. In the next section, we explore the types of agencies that presidents have brought under their authority in Argentina and Brazil since the 1980s.

\section{The Weight of the Core Units}

In the last thirty years or so, the presidencies of Argentina and Brazil have changed not only in size but also in function. Following Inácio (2012), we classify the IP units as core, advisory, and policy ones. The units in charge of managing the daily tasks of the presidency -those supporting administrative, legal, and institutional tasks - constitute the center or the core of the presidency. The presidential advisory system, which is gradually integrated with new councils and consultative bodies (technical chambers), addresses policy formulation and strategic agendas. The policy units are responsible for formulating and implementing specific policies (INÁCI0,2012, p. 09). This functional classification of the presidential units allows us to compare the makeup of the two presidencies studied here and to tentatively explore whether the type of executive cabinet not only impacts on the size but also the type of units that presidents bring under their direct authority.

In the 1980s, the IP was basically constituted by core units in both countries (see Graph 02 below, which counts the total number of core units and the number of IP units in general). After that decade, the number of core units in Argentina remained stable while the size of the whole IP increased up until the end of the 1990s. The structure of the institutional presidency has followed a different pathway in Brazil. The IP was essentially formed by a small number of core units in the beginning, which afterward grew together with the other types of units that were created by the Collor and Lula governments. Therefore, the downward and upward movements in practice mean that there were substantive changes to the internal organization of the presidency. These trends involved the creation, reform, transfer, and/or dissolution of units responsible for strengthing the 
presidential capacities to monitor and formulate policy, as well as increases in the presidency's informational resources.

Graph 02. Number of core units and IP units of the presidencies of Argentina and Brazil, 1984-2010

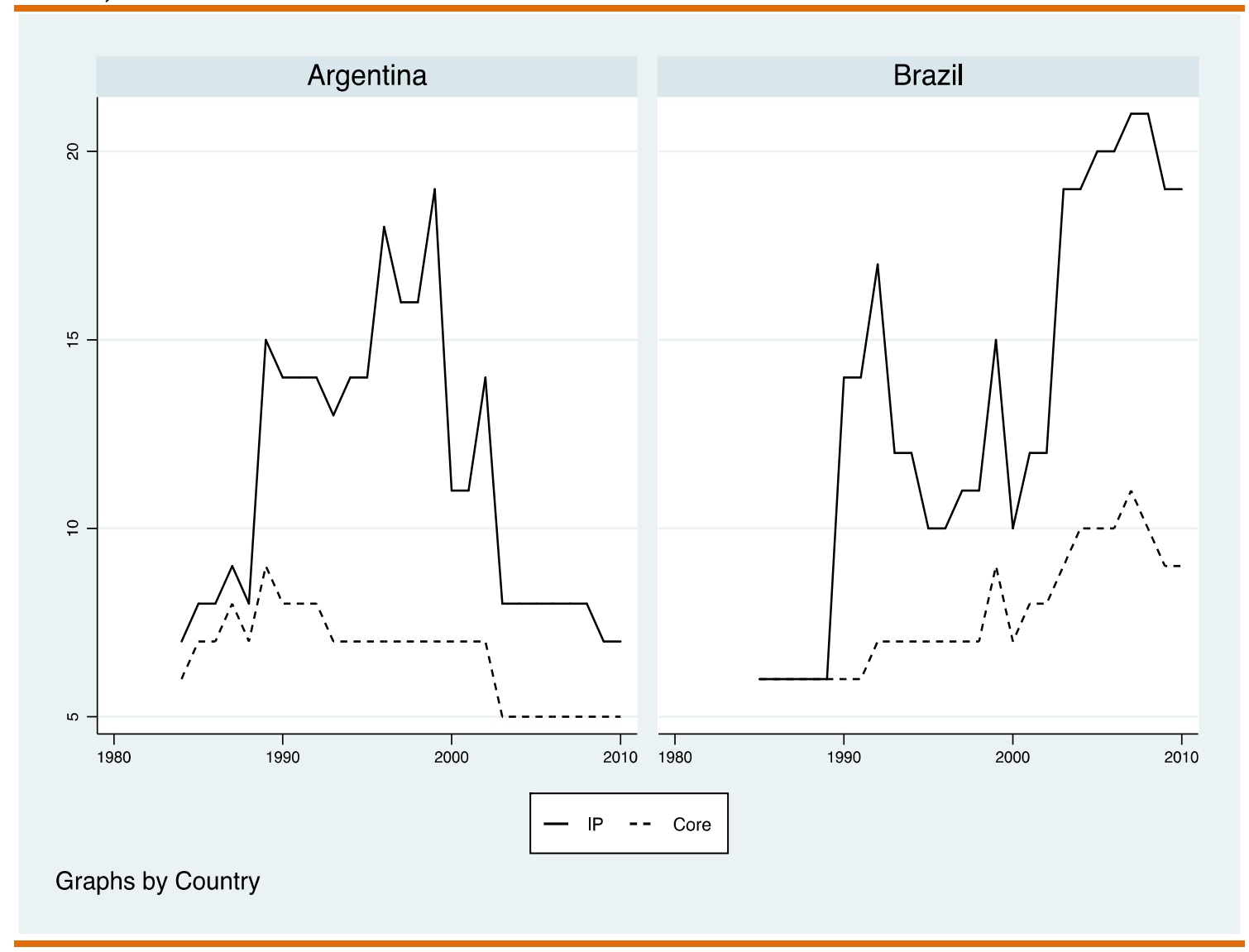

Source: INACIO_LLANOS_DATABASE.

Graph 03 depicts the percentage of each type of unit, out of the total of all IP units for the whole time period studied, in both countries. The Argentine presidency was internally less diversified, with the units oscillating only between core and policy ones. We can see in this graph that the process of unit centralization taking place in this country in the 1990s mostly concerned policy issues. The new policy units did not necessarily cover crucial areas but, rather, ones that mattered to the president: drugs, tourism, culture, science and technology, and social development. Many of them were abolished or reassigned to ministries during the following decade. The lack of advisory units is remarkable, although the core units contribute to these tasks in practice. The Brazilian picture is more diverse. The monolithic presidency of the 1980s has since been substituted by an internally differentiated and specialized institution. While the expansion of 
policy units has been attributed to specific junctures ${ }^{8}$, the creation of advisory bodies inside the presidency has in fact been a continuous process. The strenthening of the core units, by means of investment in organization and personnel, has coincided with the improvement of the informational conditions available for making presidential decisions. These advisory bodies are now in charge of providing specialized subsidies in priority areas.

Regarding the core units in Argentina, they have in essence included the General Secretariat of the Presidency, the presidential unit, the legal and technical unit, the communication and press unit, and the Secretariat of Intelligence (ALESSANDRO, 2010, p. 25; COUTINHO, 2008) - all units have a long-standing presence within the presidency. The General Secretariat endorses all the legal decisions of the presidency, while the legal area (Legal and Technical Secretariat) provides legal advice to the president, the chief of cabinet, and to the ministers that require it; it also analyzes the constitutionality of all legal decisions taken and, in general, centralizes all activities related to the legal decisions arrived at by the president. The three general, legal, and intelligence secretaries have the status of ministers. A similar structure, one with close functions, can be identified within the Brazilian presidency as well: the General Secretariat of the Presidency, the Office of Military Affairs, the Office of the Chief of Staff (Casa Civil), the Armed Forces General Staff, the General Consultation of the Republic, and the Armed Forces High Command Secretariat for Social Communication formed the initial core units in the 1990s. Following the redesign of the presidency in 1999, which culminated in the transfer of military functions to a new ministry, this core has since experienced a gradual process of transformation in its structures, alongside the creation of specialized units supporting presidential actions in strategic affairs, institutional publicity, and internal oversight.

\footnotetext{
8 This happened during the first year of Collor's and Lula's mandates. Collor carried this expansion out alongside the simultaneous abolition of several ministries, thereby centralizing functions and tasks within the presidency. Under the Lula government, meanwhile, the centralization of policies within the presidency occurred at the same time as the government increased the number of ministries (INÁCIO, 2006; 2012). In particular, Lula centralized policy formulation and implementation in new areas, such as human rights, the promotion of racial equality, and women's rights.
} 
Graph 03. Percentage of core, policy, and advisory units of the presidencies in Argentina and Brazil

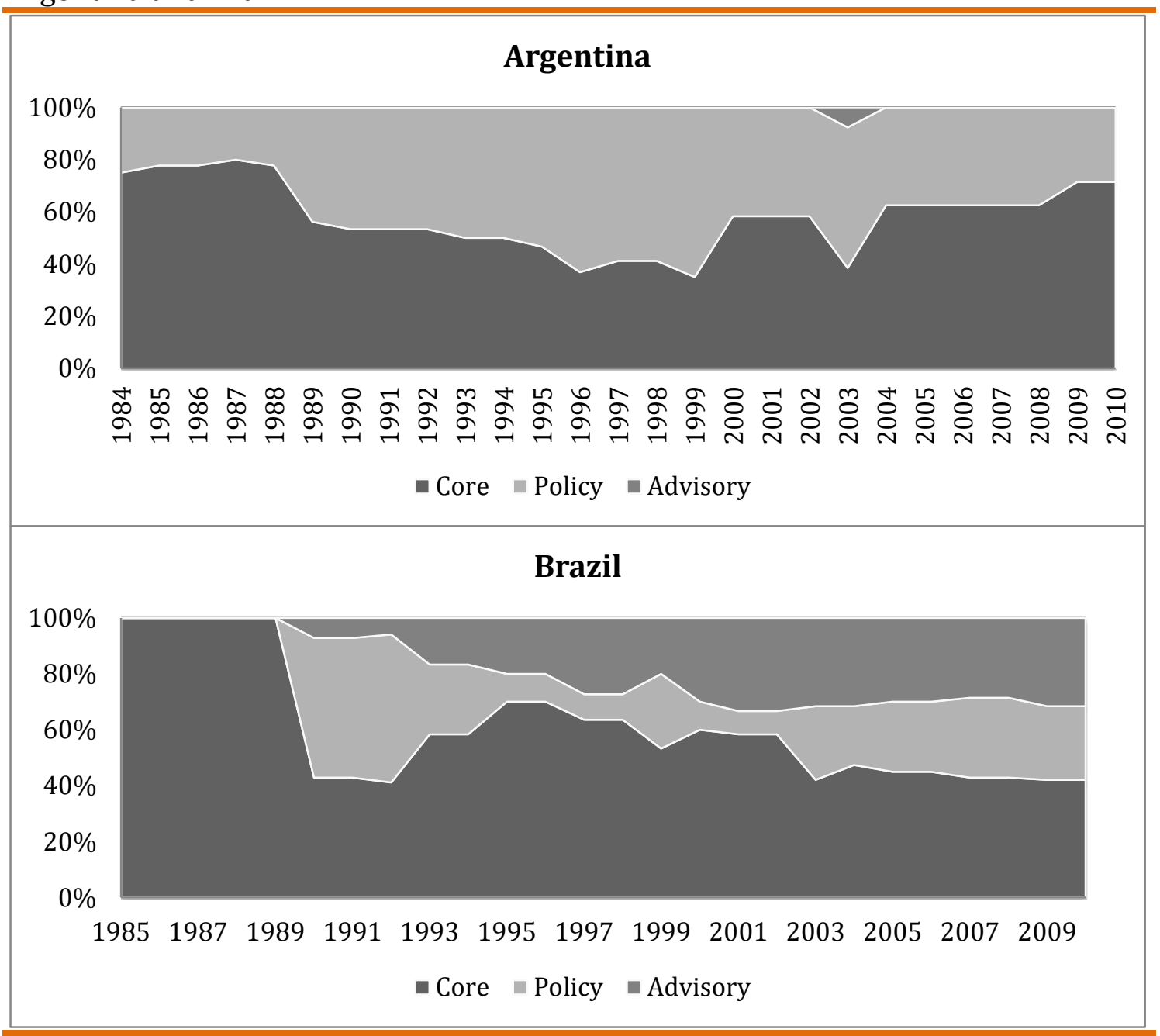

Source: INACIO_LLANOS_DATABASE.

However, one important difference between the two countries concerns the relative weight of the core units in dealing with the functions of coordination and management of the respective governments. In Argentina, a couple of coordinating and management (media, civil society) subunits today can be identified within the institutional presidency; however, the important function of political management is not under the president's authority. Instead, the Department of the Chief of Cabinet (Jefatura de Gabinete de Ministros), who is a figure with the status of a minister - having been adopted in the constitutional reform of 1994, is in charge of this. The chief of cabinet's (ChC)'s functions mainly concern interministerial coordination, congressional liaison, and the fiscal relationship between the nation and the provinces (www.jgm.gov.ar), one reason why the ChC has sometimes been referred to as the "coordinator minister". 


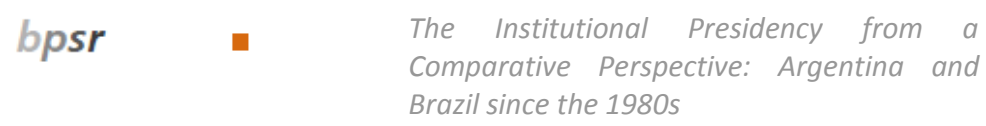

Although, according to the constitution, political responsibility for the general administration of the country is reserved for the president (Article 99), it also establishes that the $\mathrm{ChC}$ is in charge of the general administration, the execution of the budget, as well as having other responsibilities that the president could theoretically delegate. The $\mathrm{ChC}$ and the different ministers are appointed and removed by the president, but the $\mathrm{ChC}$ is politically responsible to the Congress and can be removed by a vote of censure cast by an absolute majority of both chambers (Art. 101) 9 .

During the last ten years the Jefatura has undergone a complex process of institutional differentiation and today is composed of six secretariats covering notable activities of political management such as those of Public Communication, Cabinet and Administrative Coordination, National Integration and Parliamentary Relations. The original idea that the constitutional reformers had, with the incorporation of the chief of cabinet, was indeed the decentralization of the presidential authority through the creation of a figure holding parliamentary responsibility. In practice, the $\mathrm{ChC}$ has become a crucial presidential agent particularly for activities related to political management (see also DE LUCA, 2011, pp. 45-47). However, different from Brazil, this agency is located outside the institutional presidency and all the coordinating agents that belong to it are directly subordinated to the $\mathrm{ChC}$, not to the president. This institutional design presupposes that there is a perfect understanding between the president and his chief of cabinet.

In contrast, Brazilian presidents directly head all core units - which gives them more discretion and flexibility to define how and through which specific unit(s) they will manage the cabinet. Abolished under the single-party government of Collor, the role of the Casa Civil (the Office of the Chief of Staff) was later reintroduced and, since the mid-1990s, has become a major gatekeeper in agendasetting processes within the executive branch. It has assumed a central position in the selection and review of bill proposals drawn up by the different ministers (and their parties). Similarly, it has enlarged its evaluation and coordination functions vis-à-vis governing policies as well as its control over any political nominations

\footnotetext{
9 All ministers, in fact, are capable of being impeached; such an eventuality has never happened in Argentine history, though (MOLINELLI, PALANZA and SIN, 1999).
} 
requested by ministers (INÁCIO, 2012; PRAÇA et al., 2011). Different arrangements have been in place for the political coordination of the cabinet, but they have always been inside the boundaries of the presidential office and enacted through its core units. Centralized within the General Secretariat under Cardoso's government, this function migrated - and was expanded - to the Casa Civil. Afterward, under Lula's government, it was channeled to a new and specialized unit: the Secretariat for Institutional Relations. With cabinet management being the president's business, the centrality of the core units is a resilient trait across coalition governments. Furthermore, despite the expansion of policy and advisory units, the core units have maintained their own relative weight within the country's institutional presidency.

The evolution of IP units, commented on above, reveals important tradeoffs between presidential priorities concerning the role of the institutional presidency. It is remarkable that single-party governments, as in Argentina and in Brazil $^{10}$, have expanded the presidency by centralizing the management of ordinary policies that could have been led by ministries. Under coalition governments, presidents seem more selective in their decisions about what should be centralized. Because their decisions affect the rewards that coalition members receive, coalition presidents are more careful to add new policy units that might help reduce the scope of the various ministerial portfolios.

In short, the size of the institutional presidency does not reveal the whole story behind the differences between the presidencies of Argentina and Brazil. The focus on size and internal complexity does, however, provide us with a more comprehensive impression of the organizational basis underlying presidential power in these two countries.

\section{Conclusion}

The main purpose of this study - an assessment of the impact of the type of executive cabinet on the institution of the presidency - comprises both a

10 The Collor presidency, the sole episode of non-coalitional government in Brazil during the period studied, enacted a deep centralization initiative by abolishing ministries and centralizing their functions into the hands of new IP units, alongside the creation of secretariats for implementing new policies. Under President Lula's government - the most centralized presidency in terms of governing coalitions - innovative policy units for dealing with new issues were created, but only for those left relatively uncovered by the jurisdictions of the various ministries. 


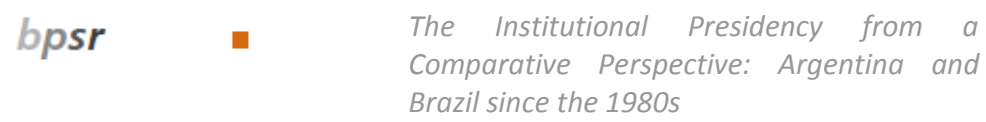

hitherto unexplored area of research vis-à-vis Latin America and an interesting agenda for the presidential literature in the future. The analysis developed in these pages provides important evidence indicating that the type of government coalitional or single-party - matters, for the variations in the architecture of the two presidencies of Argentina and Brazil, regarding both their size and functions.

It has been shown that the development of the successful Brazilian coalition presidentialism has been accompanied by a compact but highly functional institutional presidency there. To confirm whether such institutional features of the presidency are a condition of success in coalition regimes, we would need to replicate the study beyond the two cases discussed here. For this, Latin America is a rich laboratory both of successful cases, such as Chile and Uruguay, and of unsuccessful ones, such as Ecuador. However, we also need to explore in more general terms the effects of determinate forms of presidential organization on government effectiveness: in Argentina, in the 1990s and in the 2000s, two enduring single-party governments were accompanied by different presidential organizations and yet both were successful (as represented by a president being reelected in each case). It seems that the interaction between presidential agencies and the presidential leadership needs to be considered important as well.

One of the advantages of the study that we have proposed here is that the information on presidential agencies allows for the systematic comparative treatment of different cases. Other complementary studies may choose to follow, for instance, approaches based on analyses of the profile of the agents heading these agencies (their professional qualifications, political origin, and closeness to the president) as well as comparisons of the size of the presidency in terms of employees and budget. However, one limit to conducting such analysis is the availability of relevant information across countries and years, a problem that we experienced while undertaking this research. A more serious additional obstacle for comparative studies is the different level of institutionalization that we found in the respective presidencies of the Latin American region. It is foreseeable that, in some cases, the important functions that we described in this paper are in the hands of individuals, and not of agencies. This problem should not, though, discourage further investigations but, rather, direct the focus toward the important topic of presidential institutionalization. 
Revised by Peter Laspina Submitted in August 2014 Accepted in January 2015

\section{References}

ALESSANDRO, Martín (2010), El elefante en la habitación: propuestas para el estudio de la institución presidencial en la Argentina. Dirección de Investigaciones, INAP. Documento de Trabajo, $\mathrm{N}^{\circ} 02$.

ALTMAN, David (2000), The politics of coalition formation and survival in multiparty presidential democracies: The case of Uruguay, 1989-1999. Party Politic. Vol. 6, N 03, pp. 259-83.

AMES, Barry (2001), The Deadlock of Democracy in Brazil. Ann Arbor: University of Michigan Press.

AMORIM NETO, Octavio (2000), Gabinetes presidenciais, ciclos eleitorais e disciplina legislativa no Brasil. Dados. Vol. 43, Nº2, pp. 479-519.

AMORIM NETO, Octavio (2006), The Presidential Calculus: Executive Policy Making and Cabinet Formation in the Americas. Comparative Political Studies. Vol. 39, $\mathrm{N}^{\circ} 04$, pp. 415-440.

BONIFACIO, José Alberto and SALAS, Eduardo Arturo (1985), Diseño organizacional de la Presidencia en la Argentina entre 1943 y 1983. Buenos Aires: Dirección General de Investigaciones. INAP.

BONVECCHI, Alejandro and SCARTASCINI, Carlos (2014), The Presidency and the Executive Branch in Latin America: What We Know and What We Need to Know. Latin American Politics and Society. Vol. 56, № 01, pp. 144-165.

COUTINHO, María Eugenia (2008), Un análisis institucional de la organización de la Presidencia en la Argentina. Colección. Vol. 18/19, pp. 17-47.

DE LUCA, Miguel (2011), Del príncipe y sus secretarios: cinco apuntes sobre gabinetes presidenciales en la Argentina reciente. In: La política en tiempos de Los Kirchner. Edited by Andrés Malamud and Miguel de Luca. Buenos Aires: Eudeba.

DICKINSON, Matthew J. (2000), Staffing the White House, 1937- 1996: The Institutional Implications of Neustadt's Bargaining Paradigm. In: Presidential Power (Forging the Presidency for the Twenty-First Century). Edited by Robert Y. Shapiro, Martha Joynt Kumar and Lawrence R. Jacobs. New York: Columbia University Press. 


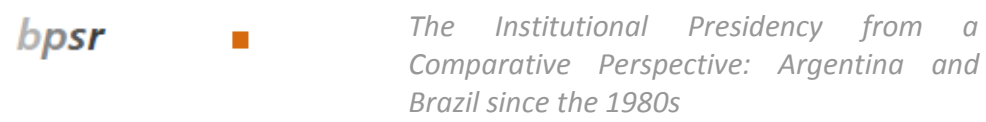

DICKINSON, Matthew J. (2005), The Executive Office of the President: the Paradox of Politicization. In: The Executive Branch. Edited by J. Aberbach and M. Peterson. Oxford: Oxford University Press.

DICKINSON, Matthew J. and LEBO, Matthew J. (2007), Reexamining the Growth of the Institutional Presidency, 1940-2000. The Journal of Politics. Vol. 69, $\mathrm{N}^{\circ} 01$, pp. 206-219.

FIGUEIREDO, Argelina and LIMONGI, Fernando (1999), Executivo e legislativo na nova ordem constitucional. Rio de Janeiro: Editora FGV.

GEORGE, Alexander and GEORGE, Juliette (1998), Presidential Personality and Performance. Westview Press.

GREENSTEIN, Fred (2009), The Presidential Difference: Leadership Style from FDR to Barack Obama (Third Edition). Princeton: Princeton University Press.

HOWELL, William (2003), Power without Persuasion. The Politics of Direct Presidential Action. Princeton and Oxford: Princeton University Press.

HUNTINGTON, Samuel (1968), Political Order in Changing Societies. New Haven, CT: Yale University Press.

INÁCIO, Magna (2006), Entre Presidir e Coordenar: Presidência e Gabinetes multipartidários no Brasil. Paper presented at $3^{\circ}$ Congresso Latinoamericano de Ciência Política, Campinas, Brasil.

INÁCIO, Magna (2012), Coalition governments and the institutional development of the Presidency in Brazil. Paper presented at Special Seminars, University of Oxford, Latin American Centre.

KRAUSE, George A. (2002), Separated Powers and Institutional Growth in the Presidential and Congressional Branches: Distinguishing Between Short-Run versus Long-Run Dynamics. Political Research Quarterly. Vol. 55 (March), pp. 27-57.

LANZARO, Jorge (2012), Introducción. In: Presidencialismo y Parlamentarismo. América Latina y Europa Meridional. Edited by Jorge Lanzaro. Madrid: Estudios Políticos.

LANZARO, Jorge (2013) Centro presidencial. Estudio sobre alto gobierno en Uruguay. Documento on line $\mathrm{N}^{\circ}$ 01. Montevideo: Instituto de Ciencia Política de la Facultad de Ciencias Sociales de la Universidad de la República.

LINZ , Juan (1990), The perils of presidentialism. Journal of Democracy. Vol. 01, $\mathrm{N}^{\circ}$ 01, pp. 51-69.

LORA, Eduardo (2012), Structural Reforms in Latin America: What Has Been Reformed and How to Measure It. IDB Working Paper Series № IDBWP346. 
MARTINEZ-GALLARDO, Cecilia (2012), Out of the Cabinet: What Drives Defections from the Government in Presidential Systems?. Comparative Political Studies. Vol. 45, N 01, pp. 62-90.

MÉNDEZ, José Luis (2007), La oficina presidencial y el liderazgo político en México y Estados Unidos: ¿Incertidumbre competitiva o certidumbre cooperativa?. Foro Internacional. Vol. XLVll, Nº4, pp. 839-867.

MÉNDEZ, José Luis (2013), Liderazgo político. Mexico: Siglo Veintiuno editores.

MEZEY, Michael (2013), Presidentialism. Power in Comparative Perspective. Lynne Rienner Publisher.

MOE, Terry (1985), The Politicized Presidency. In: The New Direction in American Politics. Edited by John E. Chubb and Paul E. Peterson. Washington, D.C.: The Brookings Institution.

MOE, Terry (1993), Presidents, Institutions and Theory. In: Researching the Presidency: Vital Questions, New Approaches. Edited by George Edwards III, John Kessel and Bert Rockman. Pittsburgh: University of Pittsburgh Press.

MOE, Terry (1994), The Presidency and the Bureaucracy: The Presidential Advantage. In: The Presidency and the Political System. Edited by Michal Nelson. Washington, D.C.: Congressional Quarterly Press.

MOLINELLI, Guillermo; PALANZA, Valeria and SIN, Gisela (1999), Congreso, Presidencia y Justicia en Argentina. Buenos Aires: Temas Grupo Editorial.

NEUSTADT, Richard (1960), Presidential Power: The Politics of Leadership. New York: John Wiley \& Sons.

PELIKAN, Jaroslav (2005), General Introduction. In: The Executive Branch. Edited by J. Aberbach and M. Peterson. Oxford: Oxford University Press.

PETERS, Guy; RHODES, R.W.A. and WRIGHT, Vincent (2000), Administering the Summit Administration of the Core Executive in Developed Countries. London: Palgrave/ Macmillan.

PONDER, Daniel E. (2012), Presidential Leverage and the Politics of Policy Formulation. Presidential Studies Quarterly. Vol. 42, N 02, pp. 300-323.

PRAÇA, Sérgio; FREITAS, Andréa, and HOEPERS, Bruno (2011), Political Appointments and Coalition Management in Brazil, 2007-2010. Journal of Politics In Latin America. Vol. 03, N 02, pp. 141-172.

RAILE, Eric D.; PEREIRA, Carlos and POWER, Timothy (2011), The Executive Toolbox: Building Legislative Support in a Multiparty Presidential Regime. Political Research Quarterly. Vol. 64, N 02, pp. 323-334. 
RAGSDALE, Lyn and THEIS III, John J. (1997), The Institutionalization of the American Presidency, 1924-92. American Journal of Political Science. Vol. 41, $\mathrm{N}^{\circ} 04$, pp. 1280-1318.

RUDALEVIGE, Andrew (2002), Managing the President's Program. Princeton, NJ: Princeton University Press.

RUDALEVIGE, Andrew and LEWIS, David E. (2005), Parsing the Politicized Presidency: Centralization, Politicization, and Presidential Strategies for Bureaucratic Control. Paper presented at the Annual Meeting of the American Political Science Association, Washington, DC.

SHUGART, Matthew S. and CAREY, John M. (1992), Presidents and assemblies: constitutional design and electoral dynamics. Cambridge: Cambridge University Press.

SKOWRONEK, Stephen (1997), The Politics Presidents Make: Leadership from John Adams to Bill Clinton. Harvard University Press. 